\title{
Altered Proopiomelanocortin Gene Expression in Adrenocorticotropin-producing Nonpituitary Tumors Comparative Studies with Corticotropic Adenomas and Normal Pituitaries
}

Yves de Keyzer, Xavier Bertagna, Frederic Lenne, François Girard, Jean-Pierre Luton, and Axel Kahn Laboratoire d'Endocrinologie and INSERM U.129, Hopital Cochin, 75014, Paris, France; and Laboratoire d'Explorations Fonctionnelles, Hôpital Trousseau, 75012, Paris, France

\begin{abstract}
In order to assess the mechanisms of proopiomelanocortin (POMC) gene expression in human ACTH-producing tumors, we performed the simultaneous evaluation of POMC products and messenger RNA (mRNA) in tissue fragments obtained from two corticotropic adenomas, five nonpituitary tumors, and two normal human pituitaries. The POMC products were examined using a combination of gel exclusion chromatography and four different radioimmunoassays directed against $\gamma_{3}$ melanocyte stimulating hormone ( $\left.\gamma_{3} \mathbf{M S H}\right)$, ACTH, $\gamma$-lipotropin ( $\left.\gamma \mathbf{L P H}\right)$, and $\beta$-endorphin. The POMCmRNA was detected and analyzed by dot and northern blot hybridization using a single-stranded genomic DNA probe corresponding to the coding region of the human POMC gene. Tissue concentrations of POMC products and mRNA showed parallel distributions. Immunoreactive $\gamma_{3} \mathrm{MSH}$ and $\gamma \mathrm{LPH}$ patterns revealed only $16-\mathrm{kD}$ fragment- and $\gamma$ LPH-like peptides in normal and tumoral pituitaries; additional $\gamma_{3} \mathrm{MSH}$ - and/or $\beta$ MSH-like peptides were found in all five nonpituitary tumors. A single POMCmRNA of $\sim 1,200$ bases (b) was detected in normal and tumoral pituitaries; a single identical POMCmRNA was also found in four nonpituitary tumors. A thymic carcinoid tumor, in addition to the 1,200-b POMCmRNA, contained equal amounts of a second larger POMCmRNA of $\sim \mathbf{1 , 4 5 0}$ b.

It is concluded that POMC gene expression appears qualitatively unaltered in corticotropic adenomas. In nonpituitary tumors, in contrast, abnormal POMC processing is frequent; in addition, an extra POMCmRNA was detected in a thymic tumor with a greater length than the normal mRNA; the mechanisms and pathophysiological implications of these modifications remain to be elucidated.
\end{abstract}

\section{Introduction}

Excess ACTH secretion in man occurs in two different circumstances: it may be secondary to a pituitary corticotropic adenoma responsible for Cushing's disease $(1,2)$; alternatively and less commonly, it may be caused by a nonpituitary tumor responsible for the ectopic ACTH syndrome (3). In both situations, inappropriately high plasma ACTH levels lead to chronic adrenal stimulation and the classical features of hypercortisolism. The

Address reprint requests to Dr. Bertagna, Endocrinologie, Pavillon Cornil, Hôpital Cochin, 27, rue du Fg St.-Jacques, Paris 75014, France.

Received for publication 25 February 1985 and in revised form 11 June 1985.

J. Clin. Invest.

(c) The American Society for Clinical Investigation, Inc.

0021-9738/85/11/1892/07 \$1.00

Volume 76, November 1985, 1892-1898 mechanisms for ACTH overproduction are unknown in both circumstances.

In recent years, however, considerable progress has been made on the molecular aspects of ACTH biosynthesis. The long suspected existence of a high molecular weight ACTH-precursor molecule $(4,5)$ was demonstrated by the biosynthetic studies performed on the ACTH-producing AtT-20/D 16-V mouse tumor cell line (6). Recombinant DNA methods eventually led to the complete characterization of this precursor called proopiomelanocortin (POMC) ${ }^{1}$ in many species (7-11), including man (12-14). The coordinate proteolysis of POMC, or processing, generates various peptide fragments: $16-\mathrm{kD}$ fragment $(16 \mathrm{~K})$, ACTH, $\beta$-lipotropin ( $\beta \mathrm{LPH})$, and a small but definite amount of $\beta$-endorphin ( $\beta$ end) and $\gamma$-lipotropin $(\gamma \mathrm{LPH})$ are formed in the anterior lobe of the pituitary (15-17). In the intermediate lobe, POMC processing goes further and smaller peptides are released, such as $\beta$-melanocyte-stimulating hormone ( $\beta \mathrm{MSH})$, corticotropin-like intermediate-lobe peptide (CLIP), and $\alpha \mathrm{MSH}$ $(18,19)$. The concept that POMC products may vary in different tissues also applies to man: several studies have shown that POMC-derived peptides are different in ACTH-producing pituitary and nonpituitary tumors (20-24). Because a single functional gene has been detected for rat, beef, and human POMC (25), it has generally been assumed that variable POMC products result from a different processing of the same precursor molecule in different tissues. However, variable expression of a single gene through an alternate mode of RNA splicing has recently been recognized as a new cause of peptide heterogeneity within, for example, the products of the growth hormone and calcitonin genes $(26,27)$. In the case of POMC itself, various forms of mRNAs have been detected in the rat $(28,29)$ and beef $(30)$ normal tissues, some of them resulting from an alternate mode of intron removal during RNA splicing (31).

Few data have been obtained so far with human ACTHproducing tissues. Two cases have been reported separately where a larger POMCmRNA species was detected in an ACTH-producing nonpituitary tumor $(32,33)$. A similar finding was also shown in metastases of medullary thyroid carcinomas (34). No studies have been performed with corticotropic adenomas, and no attempt was made to evaluate the final products of POMC in relation to its mRNA.

We have studied the mechanisms of POMC gene expression in ACTH-producing tissues in man simultaneously at the pretranslational (POMCmRNA) and posttranslational (POMC products) levels. POMC processing was studied by analyzing its

1. Abbreviations used in this paper: $\mathrm{b}$, base; BSA, bovine serum albumin; CLIP, corticotropin-like intermediate-lobe peptide; end, endorphin; $h$, human; IR, immunoreactive; $K_{d}$, fractional elution volume of column chromatography; LPH, lipotropin; MSH, melanocyte stimulating hormone; PMSF, phenylmethylsulfonide fluoride; POMC, proopiomelanocortin; RIA, radioimmunoassay; $16 \mathrm{~K}, 16-\mathrm{kD}$ fragment. 
various fragments. POMCmRNA was specifically detected by northern blot analysis in the same tissues, using a genomic DNA. probe corresponding to the coding region of the human POMC gene. The data obtained in nonpituitary tumors were compared with the data obtained in normal human pituitaries and corticotropic adenomas.

\section{Methods}

Tissue collection. Nonpituitary tumors were obtained at surgery in five patients with the ectopic $A C T H$ syndrome. $E_{1}$ to $E_{4}$ were bronchial carcinoid tumors; $E_{s}$ was a thymic carcinoid tumor. Fragments of pituitary adenomas from two patients with Nelson's syndrome $\left(\mathrm{N}_{1}, \mathrm{~N}_{2}\right)$ were obtained at surgery by the transsphenoidal approach. In all cases, macroscopically homogeneous tumor fragments with no evidence of local necrosis were quickly selected by the surgeon, immediately frozen in liquid nitrogen, and subsequently stored at $-85^{\circ} \mathrm{C}$. Two normal human pituitaries $\left(\mathrm{P}_{1}, \mathrm{P}_{2}\right)$ were obtained at autopsy 2 and $6 \mathrm{~h}$ postmortem in patients with no evidence of endocrine disease and no history of prior hormonal treatment. They were frozen and stored as indicated. Patients with ACTH-producing tumors had not been subjected to either radiotherapy or chemotherapy.

Tissue extraction. For peptide studies, tissue fragments were homogenized in ice-cold $5 \mathrm{~N}$ acetic acid $(10 \mathrm{ml} / \mathrm{g}$ tissue) containing $1 \mathrm{mM}$ phenylmethylsulfonide fluoride (PMSF), by three to five 15-s bursts in a $\mathrm{PCU}_{2}$ Polytron (Polytron Corp., Elkhart, IN). The homogenates were centrifuged at $5,000 \mathrm{~g}$ for $30 \mathrm{~min}$ at $4^{\circ} \mathrm{C}$, and the supernatants were lyophilized in multiple aliquots that were subsequently used for radioimmunoassay (RIA) and/or chromatographic studies.

RIAs. Four different RIAs scanning the entire POMC molecule were used.

The $\gamma_{3}$ MSH RIA was performed as described (24) using antibody 33-44. Synthetic bovine $\gamma_{3}$ MSH (kindly provided by N. Ling, Salk Institute, La Jolla, CA) was used as both tracer and standard. Purified human (h)16K (kindly provided by P. J. Lowry, St. Bartholomew's Hospital, London, England) showed $24.7 \%$ cross-reactivity on a molar basis. No significant cross-reactivity was observed with highly purified $h \beta L P H$, h $\gamma$ LPH (kindly provided by D. N. Orth, Vanderbilt University, Nashville, TN), synthetic hACTH, h $\beta$ MSH, $\alpha$ MSH (Ciba-Geigy Corp., Summit, NJ), hßend (Beckman Instruments, Fullerton, CA), and hCLIP (Peninsula Laboratories, Inc., Belmont, CA).

The ACTH RIA was performed using the $\mathrm{COOH}$-terminal antibody Kathy provided by B. Eipper and R. Mains (Johns Hopkins Hospital, Baltimore, MD). Synthetic hCLIP was used as both standard and tracer; hACTH showed $100 \%$ cross-reactivity. No significant cross-reactivity was observed with $\gamma_{3} \mathrm{MSH}, \mathrm{h} 16 \mathrm{~K}, \alpha \mathrm{MSH}, \mathrm{h} \beta \mathrm{LPH}, \mathrm{h} \beta \mathrm{MSH}$, or h $\beta$ end.

The $h \gamma$ LPH RIA was performed as described (22) using antiserum $\mathrm{R} 1547$ directed against the $\mathrm{COOH}$-terminal end of the molecule. Purified $\mathrm{h} \gamma \mathrm{LPH}$ was used as both standard and tracer. Synthetic $\mathrm{h} \beta \mathrm{MSH}$ showed $100 \%$ cross-reactivity. No significant cross-reactivity was observed with $\gamma_{3} \mathrm{MSH}, \mathrm{h} 16 \mathrm{~K}, \mathrm{~h} \beta \mathrm{LPH}, \mathrm{h} \beta \mathrm{end}$, or hCLIP.

The $h \beta$ end RIA was performed as described (35) using antibody $R$ 2489. Synthetic $h \beta$ end was used both as standard and tracer. Purified $\mathrm{h} \beta \mathrm{LPH}$ showed $100 \%$ cross-reactivity. No significant cross-reactivity was observed with h16K, $\gamma_{3} \mathrm{MSH}, \alpha \mathrm{MSH}, \mathrm{hCLIP}, \mathrm{hACTH}, \mathrm{h} \gamma \mathrm{LPH}$, or h $\beta$ MSH.

The lyophilized tissue extracts were redissolved in $0.1 \mathrm{~N} \mathrm{HCl}$, centrifuged at $5,000 \mathrm{~g}$ for $30 \mathrm{~min}$ at $4^{\circ} \mathrm{C}$, and the supernatant serially diluted in the appropriate buffer for RIA measurement and/or for chromatography. All results were expressed in picomoles of immunoreactive (IR) peptide per microgram of extracted protein measured by the Bio-Rad Protein Assay (36).

Sephadex G-50 gel exclusion chromatography. A $0.9 \times 60 \mathrm{~cm}$ column was packed with Sephadex G-50 Fine (Pharmacia Fine Chemicals, Div. of Pharmacia, Inc., Piscataway, NJ), which was equilibrated and developed at $4^{\circ} \mathrm{C}$ with the RIA buffer $\left(0.06 \mathrm{M} \mathrm{Na}_{2} \mathrm{HPO}_{4}, 0.012 \mathrm{M}\right.$ EDTA, $0.1 \%$ Triton X-100, $0.05 \% \mathrm{NaN}_{3}, \mathrm{pH} 7.3$ ). Samples of $0.8 \mathrm{ml}$ were applied and eluted at a flow rate of $20 \mathrm{ml} / \mathrm{h}$ (descending flow, $50 \mathrm{~cm}$ hydrostatic pressure); 1-ml fractions were collected. The column was calibrated with bovine serum albumin (BSA) as a void volume marker, $h \beta L P H, h \beta e n d$, $\mathrm{h} 16 \mathrm{~K}, \gamma_{3} \mathrm{MSH}, \mathrm{h} \gamma \mathrm{LPH}, \mathrm{h} \beta \mathrm{MSH}$ (each measured by RIA), and dinitrophenyl-alanine (DNP-Ala) as a total volume marker. BSA and DNPAla were added to each sample to determine the fractional elution volume $\left(\mathrm{K}_{\mathbf{d}}\right)$ of the IR materials for each run. Fractions eluted from the column were directly analyzed by RIA.

Isolation of RNA. Isolation of total cellular RNA was carried out by the guanidium chloride method of Cox (37), slightly modified in our laboratory (38). Briefly, frozen tissues were ground in liquid nitrogen, then homogenized at $4^{\circ} \mathrm{C}$ in a Waring blender in 20 volumes (wt/vol) of prechilled $0.02 \mathrm{M}$ sodium acetate buffer, $\mathrm{pH} 5$, containing $7 \mathrm{M}$ guanidine- $\mathrm{HCl}$. Nucleic acids were precipitated at $-20^{\circ} \mathrm{C}$ with ethanol. DNA was removed by three washes in $3 \mathrm{M}$ sodium acetate buffer, $\mathrm{pH} 5$, containing $0.5 \%$ lauroyl sarcosine. After centrifugation $\left(10 \mathrm{~min}\right.$, at $\left.-10^{\circ} \mathrm{C}\right)$ the pellet was washed twice with $80 \%$ ethanol, dried, and resuspended in sterile water. Total cellular RNA yields were in the range of $0.5-1.5$ $\mathrm{mg} / \mathrm{g}$ wet wt tissue.

Single-strand DNA probe. A 2.2-kb EcoR1 restriction fragment containing the entire third exon of the human POMC gene and cloned into pBR 325 was kindly provided by J. Shine (13). A smaller 657-bp Sma - $^{-}$ $\mathrm{Sal}_{1}$ restriction fragment was subcloned into phage $\mathrm{M} 13 \mathrm{mp} 10$ (39); this fragment is limited to the third exon and corresponds to most of the coding region for POMC, sparing the first $6 \mathrm{NH}_{2}$-terminal amino acids and overpassing the $\mathrm{COOH}$-terminal end of 35 nucleotides in the $3^{\prime}$ noncoding region.

Preparation of the POMC DNA probe was based on the same principle as M13 chain termination sequencing method. $1 \mathrm{pmol}$ of the 17 mers M13 sequencing primer (40) was added to 0.2 pmol of single stranded M13 matrix containing the POMC DNA strand identical to the mRNA. Annealing was obtained by heating the mixture at $100^{\circ} \mathrm{C}$ for $3 \mathrm{~min}$ in $0.02 \mathrm{M}$ Tris- $\mathrm{HCl}, 0.02 \mathrm{M} \mathrm{MgCl}_{2}, \mathrm{pH} 8.5$, then keeping it for $30 \mathrm{~min}$ at room temperature. $100 \mathrm{pmol} \mathrm{dATP,} \mathrm{dTTP,} \mathrm{dGTP,} \mathrm{and}$ 35 pmol ${ }^{32} \mathrm{P}-\mathrm{dCTP}$ (400 Ci/mmol; Amersham Corp., Arlington Heights, IL) were then added. The reaction mixture was made $1 \mathrm{mM}$ spermidine, $2 \mathrm{mM}$ dithiothreitol, $0.01 \mathrm{M}$ Tris- $\mathrm{HCl}, 0.01 \mathrm{M} \mathrm{MgCl}, \mathrm{pH}$ 8.5. After 1 $h$ incubation at $25^{\circ} \mathrm{C}$ with $1 \mathrm{U}$ of $E$. coli DNA polymerase I large fragment (Boehringer Mannheim Diagnostics, Inc., Houston, TX), DNA strands were denatured in $0.05 \mathrm{M} \mathrm{NaOH}, 1 \mathrm{mM}$ EDTA at $100^{\circ} \mathrm{C}$ for $2 \mathrm{~min}$, and separated by electrophoresis in $1.2 \%$ low melting point agarose alcaline gel (Bethesda Research Laboratories, Gaithersburg, MD). The labeled DNA strand was excised and boiled in $10 \mathrm{vol}$ of hybridization solution. A specific activity of $1-2 \times 10^{9} \mathrm{cpm} / \mu \mathrm{g}$ DNA was usually reached.

Dot blot quantification. Total RNA concentration was determined by $O D$ measurement at $260 \mathrm{~nm}$. Serial 1:2 dilutions of the samples were spotted onto Gene Screen plus (New England Nuclear, Boston, MA) membrane with a 96-wells minifold apparatus (Schleicher and Schuell, Keene, $\mathrm{NH}$ ) after $10 \mathrm{~min}$ denaturation at $65^{\circ} \mathrm{C}$ in $50 \mu \mathrm{l}$ of $2.2 \mathrm{M}$ formaldehyde, $15 \times$ SSC. $^{2}$ Each well was rinsed with $100 \mu$ l of the denaturing solution and the sheet was air dried. The filter was subsequently hybridized like northern blot filters. Each dot was cut and counted in a 1215 rackbeta counter (LKB Instruments, Gaithersburg, MD).

Northern blot analysis. Extracted RNA (0.1-20- $\mu \mathrm{g}$ aliquots) was denatured at room temperature for $10 \mathrm{~min}$ in $5 \mathrm{mM} \mathrm{Na}_{2} \mathrm{~B}_{4} \mathrm{O}_{7}, 0.01 \mathrm{M}$ $\mathrm{Na}_{2} \mathrm{SO}_{4}, 1$ mM EDTA, $0.05 \mathrm{M} \mathrm{H}_{3} \mathrm{BO}_{3}, 0.01 \mathrm{M} \mathrm{CH}_{3} \mathrm{HgOH}$ (41). Samples were loaded on a $2 \%$ agarose gel containing $0.01 \mathrm{M} \mathrm{CH}_{3} \mathrm{HgOH}$ and electrophoresis was performed at $100 \mathrm{~mA}$ for $4 \mathrm{~h}$ using the same buffer without $\mathrm{CH}_{3} \mathrm{HgOH}$. Transfer to Gene Screen plus sheets was carried out according to Thomas (42) and modified in our laboratory (43) and RNA was fixed onto the membrane by air drying.

Hybridization and prehybridization were carried out in the same buffer: $3 \times$ SSC, $10 \%$ dextran sulfate, $1 \%$ SDS, $1 \%$ glycine, $0.1 \%$ polyvinylpirolidone, $0.1 \%$ Ficoll, $100 \mu \mathrm{g} / \mathrm{ml}$ of denatured sheared salmon

2. $1 \times \mathrm{SSC}=0.15 \mathrm{M} \mathrm{NaCl}, 0.015 \mathrm{M}$ Tris sodium citrate. 
sperm DNA. Filters were prehybridized at $65^{\circ} \mathrm{C}$ for $4 \mathrm{~h}$, and subsequently hybridized with 2-10 $\times 10^{6} \mathrm{cpm} / \mathrm{ml}$ of POMC single-stranded DNA probe for $40 \mathrm{~h}$ at $65^{\circ} \mathrm{C}$. The filter was then washed successively twice at $65^{\circ} \mathrm{C}$ in $1 \times \mathrm{SSC}, 1 \% \mathrm{SDS}$, once in $0.5 \times \mathrm{SSC}, 1 \% \mathrm{SDS}$, and once in $0.2 \times$ SSC, $1 \%$ SDS. Filters were exposed to Kodak XAR-5 x-ray films (Eastman Kodak Co., Rochester, NY) between two Dupont Lightning Plus intensifying screens (DuPont Co., Diagnostic \& BioResearch Systems, Wilmington, DE) at $-80^{\circ} \mathrm{C}$.

\section{Results}

The tumor contents in POMC products were first estimated by direct RIA of the tissue extracts. In order to scan the entire POMC molecule, three different RIAs were used: $(a)$ The $\gamma_{3} \mathrm{MSH}$ RIA-detected peptides related to the $\mathrm{NH}_{2}$-terminal end of POMC (N-POMC). Because h16K was only $24.7 \%$ cross-reactivity, the actual molar concentration of N-POMC peptides had to be corrected by this factor once the $\mathrm{h} 16 \mathrm{~K} / \gamma_{3} \mathrm{MSH}$ ratio had been determined on G-50 gel filtration. (b) The ACTH RIAdetected peptides related to the midportion of POMC (midPOMC). (c) The hßend RIA-detected peptides related to the $\mathrm{COOH}$-terminal end of POMC (C-POMC).

As shown in Table I, within a single tissue, the concentrations of $\mathrm{N}-$, mid-, and C-POMC peptides were of the same order of magnitude. Absolute concentrations, however, were different in the various tissue extracts. Normal $\left(\mathrm{P}_{1}, \mathrm{P}_{2}\right)$ and tumoral $\left(\mathrm{N}_{1}\right.$, $\mathrm{N}_{2}$ ) pituitaries had comparable concentrations in the 1-10 pmol/ $\mu \mathrm{g}$ protein range. The nonpituitary tumors had a wide range of concentrations from similar values $\left(E_{1}\right.$ and $\left.E_{2}\right)$ down to $<0.01$ $\mathrm{pmol} / \mu \mathrm{g}$ protein.

A more precise evaluation of the POMC peptides was obtained after Sephadex G-50 gel exclusion chromatography. We selected to analyze the POMC products of the $16 \mathrm{~K}, \gamma \mathrm{LPH}$, and Bend regions that can easily be separated by this technique. As shown in Fig. 1 (upper panel), normal $\left(\mathrm{P}_{1}, \mathrm{P}_{2}\right)$ and tumoral $\left(\mathrm{N}_{1}\right.$, $\mathrm{N}_{2}$ ) pituitaries contained mainly $\mathrm{h} 16 \mathrm{~K}$ itself, with some heterogeneity in the void volume of the column. Nonpituitary tumors, in contrast (lower panel), contained in addition to $\mathrm{h} 16 \mathrm{~K}$ a smaller molecular weight material with an elution volume intermediary between that of h16K and synthetic (nonglycosylated) $\gamma_{3} \mathrm{MSH}$. As shown in Fig. 2, normal and tumoral pituitaries (upper panel)

Table I. Comparative Evaluation of POMC Peptides and POMCmRNA in ACTH-producing Tissues

\begin{tabular}{lllll}
\hline & \multicolumn{2}{l}{ POMC peptides* } & \\
\cline { 2 - 4 } & N-POMC & Mid-POMC & C-POMC & POMCmRNA \\
\hline $\mathrm{P}_{1}$ & 5.45 & 5.63 & 4.68 & 1.1 \\
$\mathrm{P}_{2}$ & 1.98 & 2.73 & 1.08 & 1.0 \\
$\mathrm{~N}_{1}$ & 5.51 & 10.2 & 3.96 & 9.0 \\
$\mathrm{~N}_{2}$ & 2.13 & 2.17 & 1.57 & 4.8 \\
$\mathrm{E}_{1}$ & 2.47 & 1.56 & 2.46 & 6.0 \\
$\mathrm{E}_{2}$ & 3.86 & 4.30 & 2.86 & 4.4 \\
$\mathrm{E}_{3}$ & 0.012 & 0.0024 & 0.0053 & 0.08 \\
$\mathrm{E}_{4}$ & 0.10 & 0.089 & 0.110 & 0.12 \\
$\mathrm{E}_{5}$ & 0.099 & 0.106 & 0.172 & 0.06 \\
\hline
\end{tabular}

* Picomoles per microgram extracted protein.

$\ddagger P_{2}$ equivalent per microgram extracted total RNA (one $P_{2}$ equivalent is the amount of POMCmRNA in $1 \mu \mathrm{g}$ of $\mathrm{P}_{2}$ total RNA).

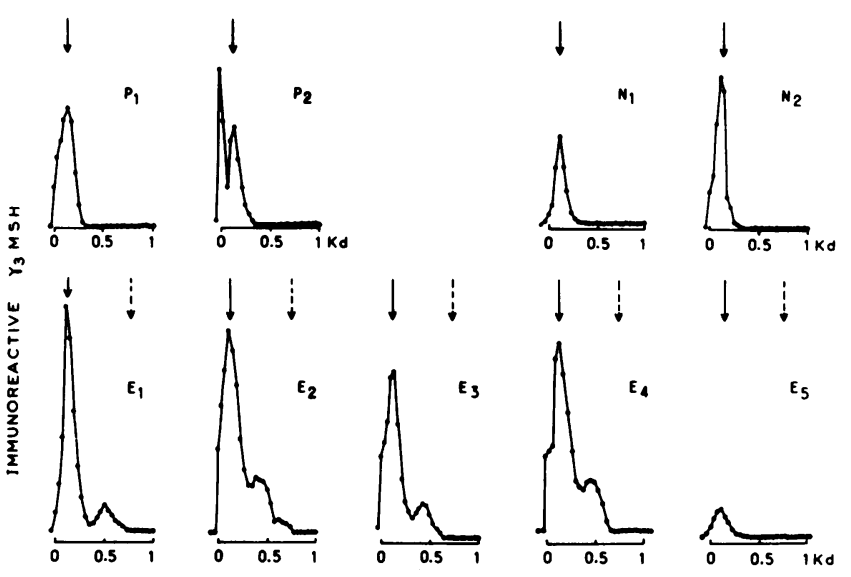

Figure 1. Sephadex G-50 gel exclusion chromatography of tissue extracts from two normal pituitaries $\left(P_{1}, P_{2}\right)$, two corticotropic adenomas $\left(\mathrm{N}_{1}, \mathrm{~N}_{2}\right)$, and five ACTH-producing nonpituitary tumors $\left(\mathrm{E}_{1}-\mathrm{E}_{5}\right)$. Each fraction was analyzed with the $\gamma_{3} \mathrm{MSH}$ RIA. The relative distributions of the IR materials (๑) are shown on a fractional elution volume $\left(\mathrm{K}_{\mathrm{d}}\right)$ scale; the variable IR $\gamma_{3} \mathrm{MSH}$ scales are purposely omitted. The positions of purified $\mathrm{h} 16 \mathrm{~K}(\mathrm{l})$ and synthetic $\gamma_{3} \mathrm{MSH}(\mathrm{i})$ are indicated.

contained only $\mathrm{h} \gamma \mathrm{LPH}$; nonpituitary tumors, in contrast (lower panel), all contained, in addition to $\mathrm{h} \gamma \mathrm{LPH}$, a smaller molecular weight peptide with an elution volume slightly but consistently larger $\left(0.75 \mathrm{~K}_{d}\right)$ than that of synthetic $\mathrm{h} \beta \mathrm{MSH}\left(0.59 \mathrm{~K}_{\mathrm{d}}\right)$. As shown in Fig. 3, variable distributions of $h \beta L P H$ and $h \beta e n d$ were observed: $h \beta$ end was present in all tissues. Whereas it was only a minor component in the two normal pituitaries $\left(\mathbf{P}_{1}, \mathbf{P}_{2}\right)$ and in one nonpituitary tumor $\left(E_{5}\right)$, it largely predominated in the two corticotropic adenomas $\left(\mathrm{N}_{1}, \mathrm{~N}_{2}\right)$ and in the four other nonpituitary tumors $\left(\mathrm{E}_{1}-\mathrm{E}_{4}\right)$.

Simple dot blot hybridization (Fig. 4) of total RNA with the POMC probe detected the presence of POMCmRNA in all tissues and allowed its quantification using a normal pituitary $\left(P_{2}\right)$

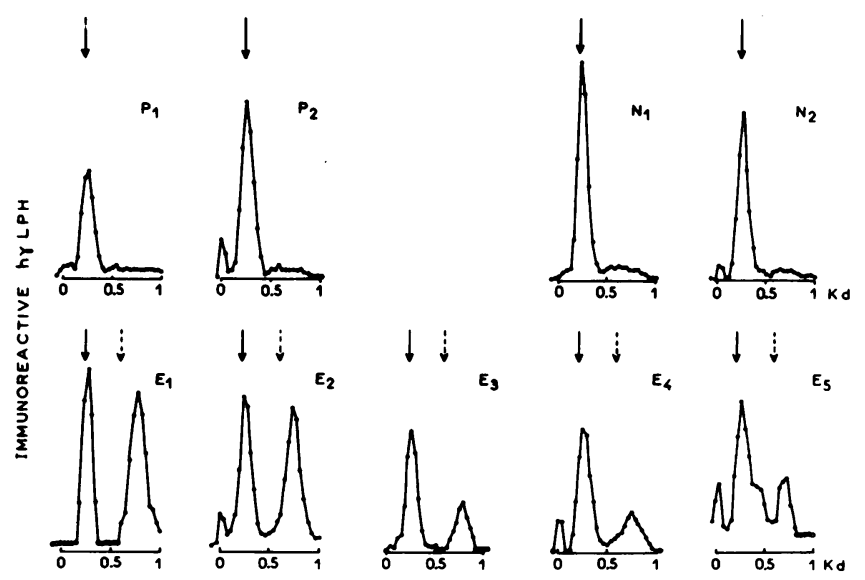

Figure 2. Sephadex G-50 gel exclusion chromatography of tissue extracts from two normal pituitaries $\left(P_{1}, P_{2}\right)$, two corticotropic adenomas $\left(\mathrm{N}_{1}, \mathrm{~N}_{2}\right)$, and five $A C T H$-producing nonpituitary tumors $\left(\mathrm{E}_{1}-\mathrm{E}_{5}\right)$. Each fraction was analyzed with the h $\gamma$ LPH RIA. The relative distributions of the IR materials $(\bullet)$ are shown on a fractional elution volume $\left(\mathrm{K}_{d}\right)$ scale; the variable IR hLPH scales are purposely omitted. The positions of purified $h \gamma L P H(l)$ and synthetic $h \beta M S H(i)$ are indicated. 


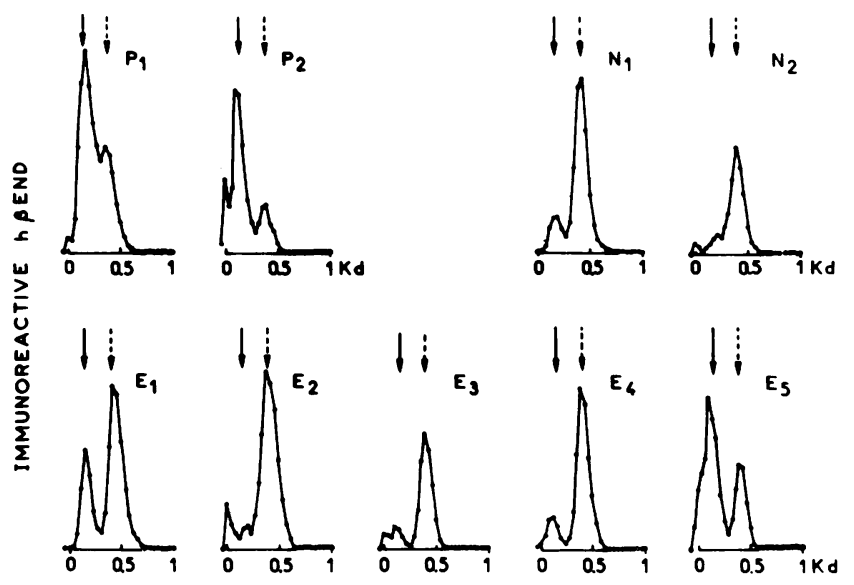

Figure 3. Sephadex G-50 gel exclusion chromatography of tissue extracts from two normal pituitaries $\left(\mathrm{P}_{1}, \mathrm{P}_{2}\right)$, two corticotropic adenomas $\left(\mathrm{N}_{1}, \mathrm{~N}_{2}\right)$, and five ACTH-producing nonpituitary tumors $\left(\mathrm{E}_{1}-\mathrm{E}_{5}\right)$. Each fraction was analyzed with the $h \beta$ end RIA. The relative distributions of the IR materials $(\bullet)$ are shown on a fractional elution volume $\left(\mathrm{K}_{\mathrm{d}}\right)$ scale; the variable IR h-end scales are purposely omitted. The positions of purified $h \beta L P H(l)$ and synthetic $h \beta$ end $(i)$ are indicated.

as an arbitrary standard. The POMCmRNA concentrations had a parallel distribution with that of POMC peptide contents (Table I) (Spearman test; $r=0.80, P<0.02$ ).

Northern blot analysis (Fig. 5) showed a single mRNA species of $\sim 1,200 \mathrm{~b}$ in normal pituitaries. $\left(\mathrm{P}_{1}\right.$, not shown here, was identical to $\mathrm{P}_{2}$ in several other northern blots.) The same results were observed in tumoral pituitaries $\left(\mathrm{N}_{1}, \mathrm{~N}_{2}\right)$. Four nonpituitary

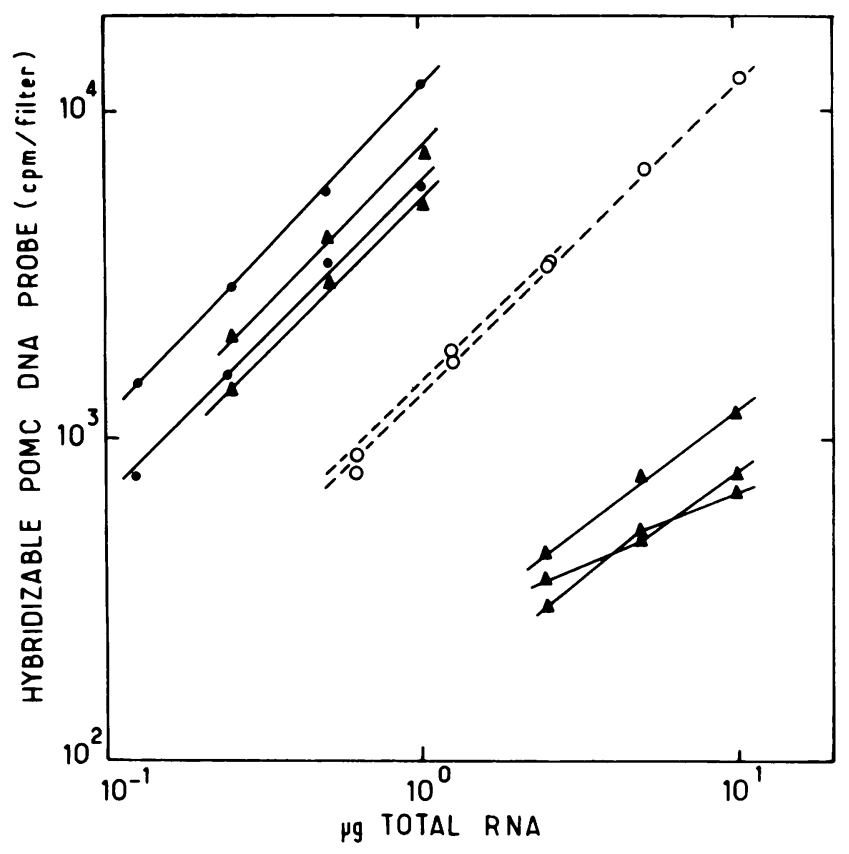

Figure 4. Dot blot quantification of POMCmRNA from two corticotropic adenomas (๑), two normal pituitaries (O), and five ACTH-producing non-pituitary tumors (A). Serial 1:2 dilutions of total RNA were dotted on a Gene Screen plus sheet and hybridized for $40 \mathrm{~h}$ at $65^{\circ} \mathrm{C}$ with $3 \times 10^{7} \mathrm{cpm}$ of POMC single-strand DNA probe. Each dot was separately counted and the results are plotted on a log-log scale. tumors $\left(E_{1}-E_{4}\right)$ also contained a single mRNA of $\sim 1,200 b$; strikingly, a thymic carcinoid tumor $\left(E_{5}\right)$, in addition to this mRNA, contained equal amounts of a larger POMCmRNA of $\sim 1,450$ b.

\section{Discussion}

A great deal of progress has been made in the last few years in the elucidation of the molecular mechanisms of POMC gene expression. It has provided the tools for a new approach in the study of ACTH overproduction by pituitary and nonpituitary tumors in man.

There are different levels where POMC gene expression may be qualitatively altered. Transcriptional and posttranscriptional (RNA splicing) modifications may lead to the production of variable $m$ RNA species. Translational and posttranslational alterations may be responsible for an inadequate POMC processing, leading to the production of variable POMC peptides. Although few isolated cases have been reported that suggest that alterations may occur at both levels, so far there are no data evaluating these two different aspects of POMC gene expression simultaneously in the same tissues.

We first examined POMC products looking for an abnormality at the posttranslational level. Four different RIAs were used in order to scan the entire POMC molecule. Concentrations of the same order of magnitude for $\mathrm{N}$-, mid-, and C-POMC peptides were always found in the same tissue. Furthermore, since mid-POMC peptides were measured by an antibody that requires a free $\mathrm{COOH}$-terminal end of the ACTH molecule, these data altogether suggested that in all our cases the POMC molecule had indeed been processed to generate its various fragments. The peculiar situation where a nonpituitary tumor may produce POMC without processing it (21) was not encountered here; this was expected, since all these patients had the clinical and biological features of Cushing's syndrome, which implies that biologically active ACTH was indeed secreted, and that POMC had thus been processed. For the same reason, the degradation of ACTH into $\alpha \mathrm{MSH}$ and CLIP, which occurs in some normal and tumoral tissues $(44,45)$, was similarly unexpected in our cases. Our strategy, therefore, was to examine more precisely the exact nature of the other POMC products.

We primarily focused our study on the $16 \mathrm{~K}$ and $\mathrm{h} \gamma \mathrm{LPH}$ regions of the POMC molecule, since both peptides (h16K and $\mathrm{h} \gamma \mathrm{LPH}$ ) are thought to be terminal products of the precursor in the normal human pituitary $(15,17)$. This was actually confirmed by the results observed in $P_{1}$ and $P_{2}$ (Figs. 1 and 2). Similarly, we did find the same final products in the two corticotropic adenomas $\left(\mathrm{N}_{1}\right.$ and $\left.\mathrm{N}_{2}\right)$. In contrast, evidence of an $\mathrm{ab}$ normal POMC processing was observed in the nonpituitary tumors: although $\mathrm{h} 16 \mathrm{~K}$ and $\mathrm{h} \gamma \mathrm{LPH}$ were present, smaller peptides with $\gamma_{3} \mathrm{MSH}$ - and $\beta \mathrm{MSH}$-like characteristics were also detected, indicating an exaggerated POMC processing. That these smaller peptides had been generated by nonspecific degradation during the extraction procedure appears highly unlikely for the following reasons. (a) Tissue extraction was performed in $5 \mathrm{~N}$ acetic acid containing PMSF as a serine protease inhibitor in order to prevent proteolysis at sites of basic amino acids, assuming that processing enzymes act at this level, through a trypsin-like effect. Actually, an enzyme acting specifically at pairs of basic amino acids has recently been characterized and purified in the yeast Saccharomyces cerevisiae and showed to be fully inhibited by 


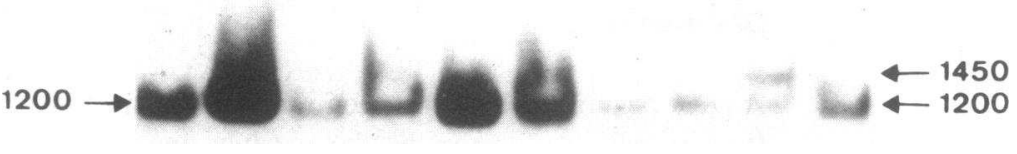

$\begin{array}{ccccccccccc} & P_{2} & N_{1} & P_{2} & E_{1} & N_{2} & E_{2} & E_{3} & E_{4} & E_{5} & P_{2} \\ \text { Total RNA(mg) } & 1 & .2 & .5 & .5 & .2 & 2 & 10 & 20 & 20 & .5\end{array}$
Figure 5. Northern blot analysis of total cellular RNA from ACTH-producing tissues. Aliquots of total RNA were first equalized to $20 \mu \mathrm{g}$ with RNase-free tRNA when necessary, then denatured in $0.01 \mathrm{M} \mathrm{CH}_{3} \mathrm{HgOH}$ for $10 \mathrm{~min}$ at room temperature. After electrophoresis on a $2 \%$ agarose gel containing $0.01 \mathrm{M} \mathrm{CH}_{3} \mathrm{HgOH}$, samples were transferred onto Gene Screen plus sheet and hybridized for $40 \mathrm{~h}$ at $65^{\circ} \mathrm{C}$ with $2.5 \times 10^{7} \mathrm{cpm}$ of POMC single-strand DNA probe. Autoradiography was performed for $30 \mathrm{~min}$ at $-80^{\circ} \mathrm{C}$ between two intensifying screens. Results obtained in two corticotropic adenomas $\left(\mathrm{N}_{1}, \mathrm{~N}_{2}\right)$, five ACTH-producing nonpituitary tumors $\left(\mathrm{E}_{1}-\mathrm{E}_{5}\right)$, and a normal pituitary $\left(\mathbf{P}_{2}\right.$, in variable amounts and at different positions on the gel), are shown.
PMSF (46). (b) The exact same extraction procedure did not generate these smaller peptides in pituitary tissues, either normal or tumoral. (c) Previous reports have shown the presence of $\gamma_{3} \mathrm{MSH}-$ and $\beta \mathrm{MSH}-$ like molecules in tumor extracts and in blood of patients with the ectopic ACTH syndrome $(22,23)$. It should be noticed that the smaller molecular weight peptides had elution volumes slightly but consistently different from that of synthetic $\gamma_{3} \mathrm{MSH}$ and $\mathrm{h} \beta \mathrm{MSH}$, respectively. It would be expected that extracted $\gamma_{3} \mathrm{MSH}$ be glycosylated (15), and therefore that its elution volume be different from that of a synthetic nonglycosylated standard. With regard to the $\beta \mathrm{MSH}$-like material, studies in progress strongly suggest that it is actually a shorter " 18 amino acids $\mathrm{h} \beta \mathrm{MSH}$ " molecule. Although the exact natures of these peptides are not yet fully established, their presence pointed to an abnormal POMC processing occurring only in nonpituitary tumors.

Scanning the C-POMC products with the $\mathrm{h} \beta$ end RIA confirmed that $\mathrm{h} \beta \mathrm{LPH}$ was the major peptide in normal pituitaries (16), and showed that $h \beta$ end was the predominant molecule in the two corticotropic adenomas and in four out of the five nonpituitary tumors. However, since definite amounts of $h \beta$ end are found in the normal pituitary, these data point to a quantitative modification of a normally present enzymatic activity in some hyperactive tissues, as already suggested by Suda et al. (47). This phenomenon appears fundamentally different from the qualitative abnormality that results in the production of $\beta \mathrm{MSH}$ - and $\gamma_{3} \mathrm{MSH}$-like peptides in nonpituitary tumors. This is best exemplified in the case of the corticotropic adenomas: while these tissues generate a major proportion of $h \beta$ end, they are not able to produce any detectable $\beta \mathrm{MSH}$ - or $\gamma_{3} \mathrm{MSH}$-like peptides. These data therefore stress the value of the latter two peptides as indicators of the qualitatively altered POMC processing that can occur in nonpituitary tumors.

We then looked at the transcriptional and posttranscriptional levels in the same tissues by specifically examining POMCmRNA. The genomic DNA probe was designed to cover most of the protein coding region of the POMC gene limited to the third exon and to avoid repetitive Alu sequences present in intron B (48). Cloning the $\mathrm{Sma}_{1}-\mathrm{Sal}_{1}$ fragment in $\mathrm{M} 13 \mathrm{mp} 10$ also allowed the production of a single-stranded DNA probe which proved highly efficient for hybridization studies using total cellular RNA. Simple dot blot hybridization showed the presence of POMCmRNA in all examined tissues. This content was correlated with that of POMC peptides, showing wide variations in nonpituitary tumors. These data strongly suggest that the rate of gene transcription is primarily responsible for the amount of peptide produced, although, theoretically at least, decreased mRNA turnover could be an alternate possibility.

In normal pituitaries a single POMCmRNA species of $\sim$ 1,200 b was observed by northern blot analysis. This molecular weight is similar to that reported by Tsukada (32) in a single normal human pituitary; it is also similar to that observed in the pituitary of various species (49). The POMCmRNA of corticotropic adenomas is first reported in this study and appears indistinguishable from that in the normal pituitary. These data thus provide evidence that in human corticotropic adenomas the mechanisms of POMCmRNA generation is not qualitatively altered at either the transcriptional or at the posttranscriptional level.

Four out of the five nonpituitary tumors also contained a single POMCmRNA species identical to that of normal human pituitary. Since these tumors had an abnormal POMC processing, it seems reasonable to assume that the second phenomenon is not related to an abnormality of gene transcription or RNA processing. It seems more likely that exaggerated POMC processing in nonpituitary tumors is caused by an abnormal enzymatic "environment," the action of which is not limited as neatly as it is in the normal (and tumoral) pituitary where only four out of nine potential "processing sites" (i.e., basic amino acid pairs) are cleaved. These data thus emphasize the role of the processing enzymes as the determinant factor of POMC processing specificity.

In one case ( $E_{5}$, a thymic carcinoid tumor) two POMCmRNAs were found: in addition to the 1,200-b mRNA species, a second larger mRNA of $\sim 1,450 \mathrm{~b}$ was detected in equivalent amounts. The two bands were present on repeated experiments and disappeared similarly after successive washes under more stringent conditions. Two isolated cases have been reported where two POMCmRNAs with characteristics identical to those of $E_{5}$ were found in a thymic carcinoid (32) and in a 
pancreatic carcinoid (33); so far no explanation is available. Partial sequencing of POMC cDNA in the second case does not indicate an abnormality in the $3^{\prime}$ region. Alternate mode of splicing is a cause of mRNA heterogeneity; in the case of POMC, Oates and Herbert (31) have shown that an abnormal removal of intron A during splicing of nuclear RNA precursor generates a second larger POMCmRNA in the rat anterior pituitary with an extra $30-b$ insertion in the $5^{\prime}$ noncoding region. The human POMC gene sequence (14) provides a theoretical acceptor splicing site in intron A (3541-3546) which would generate a larger mRNA of $\sim 1,450 \mathrm{~b}$. Another possibility would be that of an extended poly $\mathrm{A}$ tail and/or its insertion at another site since two AATAAA sequences are present on the $3^{\prime}$ flanking region of the third exon (14). Finally, an abnormal site of transcription initiation remains possible: a $250-\mathrm{b}$ difference would imply that it starts upstream from the (supposed) normal promoter region. Supporting this hypothesis, analysis of the $5^{\prime}$ flanking region reveals the following sequences: CAAACAAT $(-439$ to -432$)$ and ATATTTA ( -396 to -390 ), which could be used as an alternate promoter to initiate the transcription of the larger POMCmRNA (14).

In conclusion, these data suggest that different pathophysiological mechanisms are responsible for ACTH overproduction in pituitary and nonpituitary tumors. In the pituitary corticotropic adenoma the overall phenomenon of POMC gene expression appears qualitatively unmodified, the mRNA and peptide products all being indistinguishable from normal. The alteration, therefore, seems quantitative, pointing to a possible abnormality in the mechanisms that normally regulate the rate of POMC gene transcription. In nonpituitary tumors, in contrast, abnormal POMC processing is a frequent phenomenon which occurs in the presence of a normal POMCmRNA in most cases. The generation of an altered POMCmRNA, although probably a rare event, has been demonstrated in a thymic tumor. The exact nature and the pathophysiological implications of this larger mRNA species remain to be elucidated.

These results on hPOMC tumor expression may provide a more general model for the study of ectopic hormone production and altered posttranslational processing.

\section{Acknowledgments}

We would like to express our thanks to D. N. Orth, P. J. Lowry, B. Eipper, R. Mains, and N. Ling for their gifts of peptides and antisera, and to J. Shine for his gift of the POMC DNA probe. We are also indebted to Dr. Bloch, Dr. Derome, Dr. Merlier, Dr. Miranda, and Dr. Guillausseau for the collections of the normal human pituitaries, corticotropic adenomas, and nonpituitary tumors, and to Mrs. Verger for her secretarial assistance.

This work was supported by Institut National de la Santé et de la Recherche Médicale Contrat de Recherche Externe. 834002.

\section{References}

1. Cushing, H. 1932. The basophil adenomas of the pituitary body and their clinical manifestations (pituitary basophilism). Bull. Johns. Hopkins Hosp. 50:137-195.

2. Nelson, D. H., J. W. Meakin, and G. W. Thorn. 1960. ACTHproducing pituitary tumors following adrenalectomy for Cushing's syndrome. Ann. Intern. Med. 52:560-569.

3. Meador, C. K., G. W. Liddle, D. P. Island, W. E. Nicholson, C. P. Lucas, J. G. Nuckton, and J. A. Luetscher. 1962. Cause of Cushing's syndrome in patients with tumors arising from "non endocrine" tissue. J. Clin. Endocrinol. Metab. 22:693-703.
4. Yalow, R. S., and S. A. Berson. 1971. Size heterogeneity of immunoreactive human ACTH in plasma and in extracts of pituitary glands and ACTH-producing thymoma. Biochem. Biophys. Res. Commun. 44: 439-445.

5. Orth, D. N., and W. E. Nicholson. 1977. Different molecular forms of ACTH. Ann. NY Acad. Sci. 297:27-46.

6. Eipper, B. A., and R. E. Mains. 1980. Structure and biosynthesis of pro-adreno-corticotropin/endorphin and related peptides. Endocrinol. Rev. 1:1-27.

7. Nakanishi, S., A. Inoue, T. Kita, M. Nakamura, A. C. Y. Chang, S. N. Cohen, and S. Numa. 1979. Nucleotide sequence of cloned cDNA for bovine corticotropin- $\beta$-lipotropin precursor. Nature (Lond.). 278:423427.

8. Drouin, J., and H. M. Goodman. 1981. Most of the coding region of rat ACTH-LPH precursor lacks intervening sequences. Nature (Lond.). 288:610-613.

9. Roberts, J. L., P. Seeburg, J. Shine, E. Herbert, J. D. Baxter, and H. M. Goodman. 1979. Corticotropin and beta endorphin: construction and analysis of recombinant DNA complementary to mRNA for the common precursor. Proc. Natl. Acad. Sci. USA. 76:2153-2157.

10. Uhler, M., and E. Herbert. 1983. Complete amino acid sequence of mouse proopiomelanocortin derived from the nucleotide sequence of proopiomelanocortin cDNA. J. Biol. Chem. 258:257-261.

11. Boileau, G., C. Barbeau, L. Jeannotte, M. Chretien, and J. Drouin. 1983. Complete structure of the porcine proopiomelanocortin mRNA derived from the nucleotide sequence of cloned cDNA. Nucleic Acid Res. 11:8063-8071.

12. Chang, A. C. Y., M. Cochet, and S. N. Cohen. 1980. Structural organisation of human genomic DNA encoding the proopiomelanocortin peptide. Proc. Natl. Acad. Sci. USA. 77:4890-4894.

13. Whitfeld, P., P. Seeburg, and J. Shine. 1982. The human proopiomelanocortin gene: organization, sequence and interspersion with repetitive DNA. DNA. 1:133-143.

14. Takahashi, H., Y. Hakamata, Y. Watanabe, R. Kikuno. T. Miyata, and S. Numa. 1983. Complete nucleotide sequence of the human corticotropin- $\beta$-lipotropin precursor gene. Nucleic Acid Res. 11:68476858.

15. Seidah, N., J. Rochemont, J. Hamelin, M. Lis, and M. Chretien. 1981. Primary structure of the major human pituitary proopiomelanocortin $\mathrm{NH}_{2}$-terminal glycopeptide. J. Biol. Chem. 256:7977-7984.

16. Allen, R. G., E. Orwoll, J. W. Kendall, and E. Herbert. 1980. The distribution of forms of adrenocorticotropin and $\beta$-endorphin in normal, tumorous and autopsy human anterior pituitary tissues: virtual absence of $13 \mathrm{~K}$ adrenocorticotropin. J. Clin. Endocrinol. Metab. 51: 376-380.

17. Tanaka, K., W. E. Nicholson, and D. N. Orth. 1978. The nature of immunoreactive lipotropins in human plasma and tissue extracts. $J$. Clin. Invest. 62:94-104.

18. Scott, A. P., P. J. Lowry, J. G. Ratcliffe, L. H. Rees, and J. Landon. 1974. Corticotropin-like peptides in the rat pituitary. J. Endocrinol. 61:355-367.

19. Scott, A. P., and P. J. Lowry. 1974. Adrenocorticotrophic and melanocyte-stimulating peptides in the human pituitary. Biochem. $J$. 139:593-602.

20. Orth, D. N., W. E. Nicholson, W. M. Mitchell, D. P. Island, and G. W. Liddle. 1973. Biologic and immunologic characterization and physical separation of ACTH and ACTH fragments in the ectopic ACTH syndrome. J. Clin. Invest. 52:1756-1769.

21. Pullan, P. T., V. Clement-Jones, R. Corder, P. J. Lowry, G. M. Besser, and L. H. Rees. 1980. ACTH, LPH and related peptides in the ectopic ACTH syndrome. Clin. Endocrinol. 13:437-445.

22. Wilson, R. E., D. N. Orth, W. E. Nicholson, C. D. Mount and X. Y. Bertagna. 1981. Human $\gamma$-lipotropin radioimmunoassay: identification of immunoreactive $\gamma$-lipotropin in human plasma and tissue. J. Clin. Endocrinol. Metab. 53:1-9.

23. Ueda, M., T. Takeuchi, K. Abe, S. Miyakawa, S. Ohnami, and N. Yanaihara. 1980. $\beta$-melanocyte-stimulating hormone immunoreac- 
tivity in human pituitaries and ectopic adrenocorticotropin-producing tumors. J. Clin. Endocrinol. Metab. 50:550-556.

24. Bertagna, X. Y., D. Seurin, L. Pique, J. P. Luton, H. Bricaire, and $\mathrm{F}$. Girard. 1983. Peptides related to the $\mathrm{NH}_{2}$-terminal end of proopiocortin in man. J. Clin. Endocrinol. Metab. 56:489-495.

25. Eberwine, J. H., and J. L. Roberts. 1983. Analysis of pro-opiomelanocortin gene structure and function. DNA. 2:1-8.

26. De Noto, F., D. D. Moore, and H. M. Goodman. 1981. Human growth hormone DNA sequence and mRNA structure: possible alternative splicing. Nucleic Acid Res. 9:3719-3730.

27. Rosenfeld, M. G., S. G. Amara, B. A. Roos, E. S. Ong, and R. M. Evans. 1981. Altered expression of the calcitonin gene associated with RNA polymorphism. Nature (Lond.). 290:63-65.

28. Chen, C. L. C., P. Mather, P. L. Morris, and C. W. Bardin. 1984 Expression of pro-opiomelanocortin-like gene in the testis and epididymis. Proc. Natl. Acad. Sci. USA. 81:5672-5675.

29. Pintar, J. E., B. S. Schachter, A. B. Herman, S. Durgerian, and D. T. Krieger. 1984. Characterization and localization of pro-opiomelanocortin messenger RNA in the adult rat testis. Science (Wash. DC). 225:632-634.

30. Jingami, H., S. Nakanishi, H. Imura, and S. Numa. 1984. Tissue distribution of messenger RNAs coding for opioid peptide precursor and related RNA. Eur. J. Biochem. 142:441-447.

31. Oates, E., and E. Herbert. 1984. 5' sequence of porcine and rat proopiomelanocortin mRNA. J. Biol. Chem. 259:7421-7425.

32. Tsukada, T., Y. Nakai, H. Jingami, S. Imura, S. Tall, S. Nakanishi, and S. Numa. 1981. Identification of the mRNA coding for the ACTHlipotropin precursor in a human ectopic ACTH-producing tumor. Biochem. Biophys. Res. Commun. 98:535-540.

33. De Bold, C. R., M. E. Schworer, T. B. Connor, R. E. Bird, and D. N. Orth. 1983. Ectopic pro-opiomelanocortin: sequence of cDNA coding for $\beta$-melanocyte stimulating hormone and $\beta$-endorphin. Science (Wash. DC). 220:721-723.

34. Steenbergh, P. H., J. W. M. Hoppener, J. Zandberg, B. Roos, H. S. Jansz, and C. J. M. Lips. 1984. Expression of the pro-opiomelanocortin gene in human medullary thyroid carcinoma. J. Clin. Endocrinol. Metab. 58:904-908.

35. Bertagna, X. Y., W. J. Stone, W. E. Nicholson, C. D. Mount, and D. N. Orth. 1981. Simultaneous assay of immunoreactive $\beta$-lipotropin, $\gamma$-lipotropin, and $\beta$-endorphin in plasma of normal human subjects, patients with ACTH/lipotropin hypersecretory syndromes, and patients undergoing chronic hemodialysis. J. Clin. Invest. 67:124-133.

36. Bradford, M. M. 1976. A rapid and sensitive method for the quantitation of microgram quantities of protein utilizing the principle of protein-dye binding. Anal. Biochem. 72:248-254.
37. Cox, R. A. 1968. The use of guanidium chloride in the isolation of nucleic acids. Methods Enzymol. 13:120-129.

38. Kahn, A., D. Cottreau, D. Daegelen, and J. C. Dreyfus. 1981. Cell free translation of messenger RNAs from adult and fetal human muscle. Eur. J. Biochem. 116:7-12.

39. Messing, J. 1983. New M13 vectors for cloning. Methods Enzymol. 101:20-78

40. Messing, J., R. Crea, and P. H. Seeburg. 1981. A system for shotgun DNA sequencing. Nucleic Acid Res. 9:309-321.

41. Bailey, J. M., and N. Davidson. 1976. Methyl mercury as a reversible denaturing agent for agarose gel electrophoresis. Anal. Biochem. 70:75-85.

42. Thomas, P. S. 1980. Hybridization of denatured RNA and small DNA fragments transferred to nitrocellulose. Proc. Natl. Acad. Sci. USA. 77:5201-5205.

43. Simon, M. P., C. Besmond, D. Cottreau, P. Chaumet-Riffaud, J. C. Dreyfus, J. Sala-Trepat, J. Marie, and A. Kahn. 1983. Molecular cloning of cDNA for rat L-type pyruvate kinase and aldolase B. J. Biol. Chem. 258:14576-14584.

44. Pique, L., S. Jegou, X. Bertagna, F. Javoy-Agid, D. Seurin, M. F. Proeschel, F. Girard, Y. Agid, H. Vaudry, and J. P. Luton. 1985 Proopiomelanocortin peptides in the human hypothalamus: comparative study between normal subjects and Parkinson patients. Neurosci. Lett. 54:141-146.

45. Ratcliff, J. G., A. P. Scott, H. P. J. Bennett, P. J. Lowry, C. McMartin, J. A. Strong, and P. R. Walbaum. 1973. Production of a corticotrophin-like intermediate lobe peptide and of corticotrophin by a bronchial carcinoid tumor. Clin. Endocrinol. 2:51-55.

46. Mizuno, K., and H. Matsuo. 1984. A novel protease from yeast with specificity towards paired basic residues. Nature (Lond.). 309:556560

47. Suda, T., Y. Abe, H. Demura, R. Demura, K. Shizume, N. Tamahashi, and N. Sasano. 1979. ACTH, $\beta$ LPH, and $\beta$-endorphin in pituitary adenomas of the patients with Cushing's disease: activation of $\beta$ LPH conversion to $\beta$-endorphin. J. Clin. Endocrin. Metab. 49:475477.

48. Tsukada, T., Y. Watanabe, Y. Nakai, H. Imura, S. Nakanishi, and S. Numa. 1982. Repetitive DNA sequences in the human corticotropin-lipotropin precursor gene region: Alu family members. Nucleic Acid Res. 10:1471-1479.

49. Civelli, O., N. Birnberg, and E. Herbert. 1982. Detection and quantitation of proopiomelanocortin mRNA in pituitary and brain from different species. J. Biol. Chem. 257:6783-6787. 